\title{
Dwelling, house and home: towards a home-led perspective on dementia care
}

\author{
Wim Dekkers
}

Published online: 11 January 2011

(C) The Author(s) 2011. This article is published with open access at Springerlink.com

\begin{abstract}
Home" is well known from everyday experience, plays a crucial role in all kinds of narratives about human life, but is hardly ever systematically dealt with in the philosophy of medicine and health care. The notion of home is ambiguous, is often used in a metaphorical way, and is closely related to concepts such as house and dwelling. In this paper the phenomenon of home is explored by means of some phenomenological writings of Heidegger, Bollnow, Bachelard and Levinas. Common in their views is that being at home and dwelling mean something more fundamental than an activity we do along with other activities, such as working and travelling. Dwelling, building a house and being at home are fundamental aspects of human existence. Being human is dwelling. While exploring the relevance of this phenomenological perspective for medical theory and practice, the focus is on the care of people suffering from dementia.
\end{abstract}

Keywords Bachelard - Bollnow - Dementia - Dwelling · Heidegger · Home - House - Levinas · Metaphor · Phenomenology

W. Dekkers

Center of Ethics, Radboud University Nijmegen,

Nijmegen, The Netherlands

W. Dekkers $(\square)$

Scientific Institute for Quality of Healthcare, Radboud University Nijmegen Medical Centre, P.O. Box 9101, 6500 HB Nijmegen, The Netherlands e-mail: w.dekkers@iq.umcn.nl

\section{Introduction}

The term home plays an important role in all kinds of narratives about human life. All sorts of disciplines have contributed to our understanding of home (Perkins et al. 2002). Also in literary works, one can find metaphors used to describe positive experiences of being home. If there is one thing that we can learn from a quick scan of the use of the notion of home, it is that it is often used in a metaphorical sense. The essence of a metaphor can be described as "understanding and experiencing one kind of thing in terms and concepts of another" (Lakoff and Johnson 1980, p. 5). By using a metaphor we make a familiar thing look different and realize that two seemingly unrelated experiences have something in common. Metaphors may help us to construct a conceptual image of matters, affairs, and situations that are difficult to describe in a more rational way. Metaphors are pervasive, not only in everyday language and thought, but also in action and everyday activities. We find ourselves using metaphors because they already mean something to us and to those around us. Home is an excellent example of this intrinsic relationship between language and everyday experience.

Talking about home is complex because of the various levels of interpretation (Moore 2000). "Being at home" means something else than the more concrete "staying at home." And most of us would say that "being in the world" is a more fundamental notion than "being at home." But all these distinctions depend upon the level of philosophical consideration and the terminology used. The various interpretations of "home" overlap. Home as a fixed place of abode also has a social context, the place where one can be together with family and friends (or alone) and where one feels comfortable. Home can refer to the place of birth, a country, the place where one resides, where one 
comes from or where one is going to. As a consequence of this ambiguity, the idea of home is connected to many other notions such as: roots, house, environment, family, dwelling, intimacy, privacy, protection, security, comfort, sacredness, and paradise.

In an earlier paper I have explored the significance of home for palliative care and argued that the goal of palliative care should be "to bring the patient home" (Dekkers 2009). By exploring four interpretations of the metaphor "coming home," I have tried to contribute to our understanding of the goals of palliative care. The four interpretations of "home" and "coming home" that I have analyzed are: (1) one's own house or homelike environment, (2) one's own body, (3) the psychosocial environment, and (4) the spiritual dimension, in particular, the origin of human existence. The first interpretation refers to the physical place where one lives and dies, the second to one's bodily well-being, the third to one's psychological well-being, and the fourth to the process of dying.

The current paper is a further exploration of the relevance of the notion of home for palliative care. By and large, it mostly relates to the first and third interpretation of being at home, but it also explicitly pays attention to the fundamental view that being human is dwelling, that is, being at home. The first aim of the current paper is to present some phenomenological descriptions of home by Heidegger, Bollnow, Bachelard and Levinas, because these analyses are not well known in the field of medical philosophy. The second aim is to explore the relevance of these writings for the care of people suffering from dementia.

In the next section, I will shortly introduce the topic of home and dementia. In the section thereafter, I will place the study of home in a broader phenomenological context by introducing the idea of "home-led palliative care." I will then present the views of Heidegger, Bollnow, Bachelard, and Levinas on dwelling, house and home. In the final section I will provide some comments about the relevance of this phenomenological perspective for the care of persons with dementia.

\section{Home and dementia}

In a prize-winning video 'Going home,' produced by Vinn Bay and Tee Boon Leng, an older woman with dementia, living in an East-Asian country, goes out to buy some meat and rice for her dinner. Unfortunately, she gets lost in the crowd of the city. She is getting confused and anxious and implores a number of passers-by: "Can you show me the way home," "can you take me home," "just take me home, please" (http://www.youtube.com/watch?v=9iXPHhfk_7E). The experience of this lady is paradigmatic for what I want to discuss in this paper, that is, the significance of home for (the care of) people with dementia.

In a very general way, one can say that people suffering from dementia gradually lose cognitive capabilities, control over their bodily functions, and their grip on the world. In philosophical debates about the nature of dementia the emphasis is very much on cognitive capabilities and the "consciousness-dimension" of being human, that is, on a lack of (or loss of) personhood, autonomy, and decisionmaking capacity (Hughes et al. 2006). More recently, however, attention has also been given to the "bodydimension" of dementia through an exploration of the socalled Situation-Embodied-Agent view (the SEA-view) of the human person (Hughes 2001; Dekkers 2010). The SEAview of the human person means that to be a person is to be situated in a culture that has its own traditions and norms, in a personal history that includes one's wishes and psychological make-up, and within the social context of family, friends, and neighbours. To be a person is also to be an embodied agent. Persons have a body and are a body at the same time. The body is considered to be a fundamental source of selfhood that does not derive its agency from a cognitive form of knowledge (Leder 1990; Kontos 2005). Therefore, the idea of embodiment is essential to understand how dementia symptoms are an expression of the lived body in dementia. Finally, to be a person is to be an agent and not merely a conscious or rational being.

Empirical findings suggest that people suffering from dementia experience their life as the breakdown of a bodily smooth flow and as the loss of the taken-for-granted way of being-in-the-world. Based on qualitative empirical research, Phinney and Chesla (2003) have described three ways in which people suffering from dementia experience this disruption of the skilled habitual body: Being slow is about the lived body slowing down as activity becomes halting. Being lost is about people's difficulty finding their way in an unfamiliar world, being lost in the world of space, of equipment, and of activity. Being a blank is about being in an empty world wherein people are unable to find the thoughts and words that make it possible for them to engage in a reflective act.

In a very general way, the key problem of dementia might be described as the loss of a common shared world of meaning, that is, the loss of a common home. Behind the question 'where am I?,' which is often being asked by disoriented persons, fundamental questions might be hidden such as 'who am I?' and 'where is my home?' (Hertogh and The 2008). As the video 'Going home' demonstrates, people with dementia want to go home or to be at home. For many patients in a psychogeriatric institution "home" appears to be a key word (Meijer 1992, 1993). People with dementia who live in a nursing home often say they have to go home because they think their 
children are coming home from school. They often search diligently for a safe home in the sense of spiritual familiarity and security. Listening to songs that they know from their childhood can enhance feeling at home. Also, caregivers in psychogeriatric institutions think in terms of home. A qualitative empirical study investigating what professional caregivers working in nursing homes consider to be a good life for residents suffering from dementia showed that "homeliness/good atmosphere in living situations" belonged to the concepts which were most often mentioned by respondents (Kalis et al. 2005).

In this paper I will lay the ground for a further exploration of what people suffering from dementia and their caregivers mean when they express themselves in terms of home. What does home mean to them?

\section{Lifeworld-spatiality-home}

Starting with the writings of Husserl, a rich and influential phenomenological tradition exists, in which the lifeworld of human beings takes a central place (Toombs 2001). 'Lifeworld' is a complex notion. In line with Husserl, it can be understood as an experienced world of meaning. It has been described as a "textured, embodied, experienced world of coloured trees, sparkling stars, alternative ways home, remembered seasons, happiness, joy, anguish and sadness" (Todres et al. 2007, p. 55). Crucial constituents of the lifeworld that have been recognized and described by Husserl and other phenomenologists are: (1) temporality, (2) spatiality, (3) intersubjectivity, (4) embodiment and (5) mood (Todres et al. 2007).

This paper primarily focuses on the second constituent of the lifeworld mentioned, that is, spatiality. Spatiality refers to our being a part of the physical environing world. Although house and home also have much broader connotations, they primarily refer to spatiality. In my view, it is worthwhile to specifically focus on house and home as an exemplary way of describing the human being's spatiality, its lifeworld, and the human condition as such. It should be noted here, however, that, in line with a holistic approach of the lifeworld, the five constituents just mentioned imply one another and are intertwined. As I will demonstrate in this paper, this intertwining regards the various interpretations of home as well. As has been analyzed by Jacobson (2009), the notion of home relates to embodiment, for example, to the Merleau-Pontian notion of the lived body. Our experience of being at home in a bodily way is essential to our nature as being in the world.

While focusing on home as a particular aspect of the spatiality of the lifeworld, I will lay the ground for a switch from (and further specification of) a "lifeworld-led health care" as has recently been introduced (Todres et al. 2007; Dahlberg et al. 2009) to a "home-led healthcare."

Heidegger, Bollnow, Bachelard and Levinas belong to those phenomenological philosophers who have given home a central place in their writings. ${ }^{1}$ Phenomenology has many faces. Heidegger and Levinas are commonly categorised among the phenomenologists, but for Bollnow and Bachelard this is less self-evident. In his standard work The Phenomenological Movement, Spiegelberg (1982) devotes a whole chapter to Heidegger and Levinas as well. Bollnow, however, is only mentioned in a note referring to his book Das Wesen der Stimmungen (Spiegelberg 1982, p. 418). Spiegelberg (ibid., p. 18) uses exactly twelve lines to explain why he did not pay attention to Bachelard, even though Bachelard explicitly calls himself a phenomenologist. His phenomenology, however, is very different from Husserl's pure phenomenology with which he did not want to be associated. Bachelard's phenomenology is "materialistic" in nature. While many phenomenologists focus on the human body, Bachelard's main interest is in the material aspects of the world, the direct surroundings of a human being: houses, huts, rooms, attics, cellars, corners, drawers, chests, locks and wardrobes. ${ }^{2}$

I selected the four authors mentioned on the following grounds. First, they can all be called phenomenologists in a particular meaning of the term. Second, they all wrote thoughtful papers on dwelling, house and home in the fifties and sixties of the twentieth century. Third, they all present their views of home in the context of the five constituents of the lifeworld and stress that dwelling, building a house and being at home are fundamental aspects of human existence. The selected writings are:

\footnotetext{
1 Also the Flemish philosopher Jacques de Visscher must be mentioned. In his many writings on architecture, house, home, and dwelling, the writings of the four philosophers mentioned here play an important role. See, for example: de Visscher (1991, 1998, 1999, esp. Chap 4 and 5). A fine example of a phenomenological exploration of home is the research project on the notion of home under the leadership of Max van Manen of the University of Alberta (Edmonton, Canada), who is also the founder of the web based project Phenomenology Online: http://www.phenomenologyonline.com/ home.html (acccessed July 16 2010).

2 Bachelard's position is interesting for another reason, because he insists upon a radical difference between metaphor and image. He acknowledges that a metaphor might give concrete substance to an experience that is difficult to put in other words, and that this experience is related to another thing from which it differs. He argues, however, that a metaphor is completely different from an image. In his view, an image owes its entire being to the imagination. He calls an image "the pure product of absolute imagination" (Bachelard 1964, p. 75). According to Bachelard, a metaphor cannot be studied phenomenologically. At most it is a "fabricated image" (ibid., p. 75). He goes on to say: "A metaphor is a false image, since it does not possess the direct virtue of an image formed in spoken revery" (ibid., p. 77).
} 
- Heidegger, Building Dwelling Thinking (Bauen Wohnen Denken 1954);

- Bollnow, Lived-Space (Der erlebte Raum 1960);

- Bachelard, The Poetics of Space (La poétique de l'espace 1957);

- Levinas, Totality and Infinity (Totalité et infini 1961).

\section{Martin Heidegger (1889-1976): the so-called fourfold}

"To preserve the fourfold, to save the earth, to receive the sky, to await the divinities, to escort mortals-this fourfold preserving is the simple nature, the presencing, of dwelling" (Heidegger 1971, p. 158-159).

In Sein und Zeit Heidegger (1927) describes the basic constitution of human "Dasein" in a formal way as "beingin-the world." ${ }^{3}$ In Building Dwelling Thinking he takes a more concrete approach to describe the way in which human beings are on earth: "To be a human being means to be on the earth as a mortal. It means to dwell" (Heidegger 1971, p. 147). The first part of the essay deals with the question of what it means to dwell. According to Heidegger, we are inclined to think that we build a house or a shelter in order to dwell somewhere, so that we attain to dwelling by means of building. From this perspective, dwelling and building are related as end and means. Heidegger, however, criticizes this end-means relationship. In his view, building is not merely a means and a way towards dwelling: building is really dwelling, and dwelling is the manner in which human beings are on earth. ${ }^{4}$ Only if we are capable of dwelling, we can build. "We do not dwell because we have built, but we build and have built because we dwell, that is, because we are dwellers" (ibid., p. 148). This "being a dweller" not only refers to an anthropological characteristic of human beings, but also implies a kind of imperative. Human beings ever search anew for the nature of dwelling and they must ever learn to dwell.

\footnotetext{
3 As Svenaeus (2000, 2001, 2002) explains, in Sein und Zeit the notions of "homelikeness" ("Heimischkeit") and "unhomelikeness" ("Unheimlichkeit") play a crucial role. According to Heidegger, unhomelikeness is, even in our everyday modes of being-in-theworld, a basic aspect of our existence, but in our everyday life it is hidden by the dominant being-at-home in the world. Consequently, the being-at-home of the human being is also a being not quite at home in this world: this is my world but it is also not entirely mine. Therefore, health can be understood as a being-at-home that keeps the fundamental homelessness of human existence - the not being at home in the world-from becoming apparent.

${ }^{4}$ To explain this, Heidegger refers to the original meaning of the German verb "bauen" (to build), that is, to dwell, to remain, to stay in a place. The old German word "bauen" says that man is insofar as he dwells, but it also means at the same time to cherish and protect, to preserve and care for, specifically to till the soil and to cultivate the vine.
}

It appears that "being at home" in Heidegger's writings does not always have the same meaning. He writes: "The truck driver is at home on the highway, but he does not have his shelter there; the working woman is at home in the spinning mill, but she does not have her dwelling place there; the chief engineer is at home in the power station, but he does not dwell there" (ibid., p. 143). It appears from this quotation that "being at home" is used here in a weak sense compared to the pregnant meaning in Sein und Zeit. In Building Dwelling Thinking, being at home means something like having practical knowledge of the situation and knowing how to act. Being at home (in this weak sense) is therefore different from dwelling somewhere. ${ }^{5}$

In a next step, Heidegger broadens his scope, paying attention not only to physical, but also to inter-relational and theological aspects of dwelling. I am referring here to his theory of the so-called fourfold (in German: "Geviert"), that is, the earth, the sky, the divinities and fellow human beings. In Building Dwelling Thinking, Heidegger does not provide much ontological foundation for the idea of the fourfold. He simply argues that "on the earth" already means "under the sky," and that both of these also mean "remaining before the divinities," and include a "belonging to men's being with one another" (ibid., p. 149). The fourfold means that there are four aspects that are one at the same time: "By a primal oneness the four-earth and sky, divinities and mortals-belong together in one" (ibid, p. 149). This means that, when we say "earth," we are already thinking of the other three along with it, however, without giving thought to the "simple oneness of the four" (ibid, p. 149). The same holds for the sky, the divinities and other mortal human beings respectively.

Although in Building Dwelling Thinking an ontological foundation of the fourfold is missing, Heidegger's analysis is insightful for two reasons. First, it reminds us of his earlier description of human "Dasein" as "being-in-theworld." The basic character of dwelling is to spare and to preserve. Mortal human beings are in the world (they dwell) by preserving the fourfold, that is, by saving the earth, receiving the sky, awaiting the divinities and initiating their own nature. Second, the idea of the fourfold illustrates that dwelling not only refers to an activity amidst a material environment, but also to the psychosocial and existential dimensions of human existence: being human is dwelling, that is, staying with and among things (ibid., p. 157).

The second part of Building Dwelling Thinking deals with the question how building, in the sense of constructing

\footnotetext{
5 This weak interpretation comes close to the metaphorical meaning of being at home as "easy motion through a landscape" (Krasner 2006, p. 211). A person who is at home can move "fluidly through the dwelling because body-subject knows that space intimately" (Seamon, citation in Krasner 2006).
} 
things, belongs to dwelling. Part of Heidegger's analysis is the example of a bridge. And again, Heidegger turns around our primary and intuitive clarification of the function of a bridge. We are inclined to say that building a bridge is adding something to an already existing location, for example, by viewing the function of a bridge as a connection between the two banks of a river. According to Heidegger, however, a specific location rather comes into existence by virtue of the bridge. The bridge creates a new location. The bridge "gathers the earth as landscape around the stream" (ibid., p. 152) and "gathers to itself in its own way earth and sky, divinities and mortals" (ibid., p. 153).

The example of the bridge is a stepping stone towards an analysis of space and boundaries. In Heidegger's view, the bridge is a thing which allows "a space into which earth and heaven, divinities and mortals are admitted" (ibid., p. 155). A space is something that has been made room for, something that is cleared and free for settlement and lodging, within a certain boundary. A boundary is not that at which something stops, but at which something else begins to be present. It is the issue of space and boundary that Bollnow concentrates on as well.

\section{Otto Friedrich Bollnow (1903-1991): inner and outer space}

"Man carves out of universal space a special and to some extent private space and thus separates inner space from an outer space" (Bollnow 1961, p. 33).

In Lived-Space Bollnow (1961) argues that philosophy at that time was mostly concerned with the problem of the temporal structure of human existence and neglected the spatial constitution of human life. ${ }^{6}$ According to him, we need a thorough reflection on the problem of lived space. The term lived space ("erlebter Raum") is analogous to the title of Minkowski's book Lived Time (Le temps vécu 1933). Since then, the notions "lived time" and "lived space" (and also "lived body" and "lived experience") have belonged to the intellectual instruments of phenomenologists. According to Bollnow, we need to approach the problem of lived space "with the least possible prejudice" (Bollnow 1961, p. 31) and to enquire into the inner

\footnotetext{
${ }^{6}$ Also in Neue Geborgenheit [New Security] Bollnow (1955) devotes one chapter to 'The Meaning of the House'. The broader context of this book is a critique of an existentialist view of the human being in which the focus is on notions such as despair (Kierkegaard), anxiety (Heidegger) and nausea (Sartre) and the image of a human being as a traveller (homo viator) and as a refugee ever under way. According to Bollnow, a human being fulfils his existence by dwelling. Dwelling and finding a (new) security is the very "essence" of his existence. Being home or homelike being in the world is an existential aspect of human beings not reducible to an underlying negative experience as it is in Heidegger's analysis.
}

structure of space, as it concretely appears in our experience. This is clearly the language of a phenomenologist for whom the concrete lived space, the space in which a human being perceives and moves, is entirely different from the abstract space of mathematicians and scientists. The lived space is "above and below, fore and aft, right and left, by the direction scheme founded in the human body" (ibid., p. 32).

Considering the human being's possibility of movements in any direction in the lived space, Bollnow asks the question: "Where is my real home?" (ibid., p. 32). It is in the context of this question that he analyses the house, which he calls "the spatial center of the life of the individual" (ibid., p. 33).

First, for Bollnow, as it is for Heidegger, dwelling is a central notion. According to him, a human being, whom he calls "a fugitive on earth" (ibid. p. 33), gains a stay by rooting himself tight to the ground with the solid walls of his house. Dwelling somewhere is fundamental for human beings. To dwell is not an activity like any other activity, but a determination of human beings in which they realize their true existence. Bollnow writes, "man needs a firm dwelling place if he is not to be dragged along helplessly by the stream of time" (ibid., p. 33).

A second characteristic of the house is related to the difference between the inner and outer space. By building a house, man carves out of the universal space a special and private space. The walls of a house represent the boundary between inner and outer space. The outside world is characterized by three concepts: (1) breadth as contrasted with the narrowness of the house, (2) strangeness as contrasted with what is known to a human being, and (3) distance as contrasted with the closeness in the house. In contrast to the outer space of "openness, of danger and abandonment," the space of the home provides a protected and hidden area, in which the human being "can be relieved of continual anxious alertness, into which he can withdraw in order to return to himself" (ibid., p. 33).

Third, the boundary between inner and outer space is not a fixed one. ${ }^{7}$ Moreover, we can cross that boundary. Inside and outside are not just elements in an objective geometrical space to be described along a couple of objective axes. The fact that a house has doors and windows, demonstrates the Heideggerian interpretation of a threshold, that is, a boundary as something to cross or as an invitation to pass. Although the house is an area of security and peace, a human being would pine away if he locked himself in his house to escape the dangers of the outside world. He must

\footnotetext{
7 Bollnow (1961) adds that the boundary between the security of the inner space and the insecurity of the outer space in fact is a gradual one. Around the individual house is a broader area that can also be called a home (in German "Heimat").
} 
go out into the world to fulfill his role in life. Security and danger both belong to the human condition, and consequently to both areas of the lived space. Human beings need a link between inner and outer space, that is, openings in the wall of the house: doors and windows. The phenomenon of a threshold as an invitation to pass is a key element in the analysis of the relationship between inner and outer space (De Visscher (ed.) 1998).

\section{Gaston Bachelard (1884-1962): reading houses}

"Every corner in a house, every angle in a room, every inch of secluded space in which we like to hide, or withdraw into ourselves, is a symbol of solitude for the imagination; that is to say, it is the germ of a room, or of a house" (Bachelard 1964, p. 136).

The titles of some of Bachelard's books, for example The psychoanalysis of fire, Water and dreams, Air and revery, and The earth and the reveries of the will, reflect his interest in the Greek classical four elements as they have been developed by Empedocles and others: earth, water, air and fire. Compared to Heidegger's scheme of the fourfold, that is, the earth, the sky, the divinities and fellow human beings, it is primarily the earth that has attracted Bachelard's attention. Bachelard's main interest is in the material aspects of the world, the direct surroundings of a human being. His writings are, so to speak, rooted in the soil of everyday life. He is especially interested in houses, huts, rooms, attics, cellars, corners, drawers, chests, locks and wardrobes, but also in animal nests and shells. The reason for his interest in animal housing is that writers and poets often compare the house or home of human beings with animal shelters.

Bachelard starts the introduction of Poetics of Space as follows: "A philosopher who has evolved his entire thinking from the fundamental themes of the philosophy of science, and followed the main line of the active, growing rationalism of contemporary science as closely as he could, must forget his learning and break with all his habits of philosophical research, if he wants to study the problems posed by the poetic imagination" (Bachelard 1961, p. xv). "Poetic imagination" is a key term in Bachelard's phenomenology. He describes the phenomenology of imagination as "a study of the phenomenon of the poetic image when it emerges in the consciousness as a direct product of the heart, soul and being of man, apprehended in his actuality" (ibid., p. xviii). In order to specify what a phenomenology of the image can be, he continues, we need to specify "that the image comes before thought" (ibid., p. $\mathrm{xx})$. Bachelard criticizes what he calls a phenomenology of the mind and writes: "We should have to say that poetry, rather than being a phenomenology of the mind, is a phenomenology of the soul. We should then have to collect documentation on the subject of the dreaming consciousness" (ibid., p. xx).

Here are a few more quotations to illustrate Bachelard's very peculiar way of thinking and writing:

"If I were asked to name the chief benefit of the house, I should say: the house shelters daydreaming, the house protects the dreamer, the house allows one to dream in peace" (ibid., p. 6).

"The great function of poetry is to give us back the situations of our dreams. The house we were born in is more than an embodiment of home, it is also an embodiment of dreams" (ibid., p. 15).

"A phenomenologist [...] takes the image just as it is, just as the poet created it, and tries to make it his own [...]. He brings the image to the very limit of what he is able to imagine" (ibid., p. 226).

As these quotations demonstrate, Bachelard's phenomenology is far removed from Husserl's concept of phenomenology. For Bachelard, phenomenology is first of all a phenomenology of images rather than of thoughts. Second, phenomenology should primarily focus on images as they are provided by poetry and daydreams. Third, people need houses in order to daydream and to imagine. They need a nest for dreaming. According to Bachelard, it therefore makes sense to say that we "write a room," "read a room", or "read a house" (ibid., p. 14). The reading of poetry is essential to grasp the specific human values of the material world around us. Bachelard also speaks about "poetic creation" and "poetic power." That is why his book contains a lot of quotations from Rilke, Baudelaire, George Sand, Rimbaud, Paul Valery and many other poets and novelists.

Although "home" and "house" have often been used interchangeably, it makes sense to make a distinction between the two concepts. The notion of home emphasizes much more than the notion of house its psychological significance to individuals and its cultural, normative, and moral meaning. Bachelard writes: "A house is first and foremost a geometrical object, one which we are tempted to analyze rationally. Its prime reality is visible and tangible, made of well hewn solids and well fitted framework. [...] But transposition to the human plane takes place immediately whenever a house is considered as space for cheer and intimacy, space that is supposed to condense and defend intimacy" (ibid., p. 48). It appears from this quotation that Bachelard somehow seems to blur the common distinction between house and home, but he also emphasizes that being home is not just living in a house.

Bachelard's phenomenology of the house is very concrete in the sense that he is interested in the meaning of all the different places of a house, varying from the kitchen to 
the sleeping room and from drawers to cupboards. An example is the verticality of the house. Verticality consists of the polarity of cellar and attic, in particular of the opposition of the irrationality of the cellar to the rationality of the roof. In his view, verticality is one of the principal themes that a phenomenology of the house can provide us (ibid., p. 18-29). It needs, however, some creative imagination from the reader to understand the opposition of the rationality of the roof to the irrationality of the cellar. In the words of Bachelard: when we dream of heights we are in the rational zone of intellectualized projects; up near the roof all our thoughts are clear. The cellar on the other hand is first and foremost "the dark entity of the house" (ibid., p. 18). When we dream there, we are in harmony with the irrationality of the depths.

\section{Emmanuel Levinas (1906-1995): home as the condition of life}

"The home, as a building, belongs to a world of objects. But this belongingness does not nullify the bearing of the fact that every consideration of objects, and of buildings too, is produced out of a dwelling" (Levinas 1971, p. 151).

In Totality and Infinity, Levinas (1971) devotes one chapter to "The dwelling." This chapter can be interpreted as a discussion with Heidegger, but there are no references to Bollnow and Bachelard. Still, most of Levinas' thoughts are in line with the basic views of the other three philosophers, namely that dwelling is an essential characteristic of being human. ${ }^{8}$ Therefore, I confine myself here to a few comments.

According to Levinas, the home is not to be considered as just an instrument (for example, to serve as a shelter against the weather) amidst many other instruments that human beings have at their disposal. Within the "system of finalities in which human life maintains itself" (ibid., p. 152), home occupies a privileged place. Although one can enjoy living in a home, the privileged role of the home does not consist in being the end of human activity but in being its condition and in this sense, its commencement.

Like Bollnow, Levinas opposes Heidegger's descriptions in Sein und Zeit. According to Heidegger, being not at home is a fundamental aspect of our existence, although it in our everyday life is hidden by the dominant being at home in the world (Heidegger 1927, p. 188). As Bollnow (1955) argues, being at home in the world is an existential aspect of human beings and not reducible to an underlying negative experience as it is in Heidegger's analysis. Also

\footnotetext{
${ }^{8}$ Levinas writes: "To exist [...] means to dwell" (Levinas 1971, p. 156) and "With the dwelling the latent birth of the world is produced" (ibid., p. 157).
}

for Levinas, being at home is a necessary condition for living our lives in the outside world. He writes: "Man abides in the world as having come to it from a private domain, from being at home with himself, to which at each moment he can retire" (Levinas 1971, p. 152). Being at home is the starting point and goal at the same time of our being in the world. A human being "goes forth outside from an inwardness" (ibid., p. 152).

This view of Levinas means that the dwelling is not situated in and being derived from an objective world. Rather, the objective world is situated in relation to the dwelling. My dwelling constitutes the outside world. This view also means a critical stance towards the idea of an idealistic knowing subject for whose eyes the world develops and opens up. Dwelling is basic to human existence. It might be considered as having the same function as the thinking consciousness in Descartes' philosophy. Levinas rejects the Cartesian dichotomy of an external world in which consciousness takes part through the senses. Our consciousness is already incarnated in the world. "Hence the subject contemplating a world presupposes the event of dwelling, the withdrawal from the elements [...], recollection in the intimacy of the home" (ibid., p. 153).

Levinas describes dwelling as "a recollection, a coming to oneself, a retreat home with oneself as in a land of refuge, which answers to a hospitality, an expectancy, a human welcome" (ibid., p. 156). According to him, the primordial function of the home does not consist in orienting our being in the world by the architecture of the building and in the discovery of a site, but in "breaking the plenum of the element, in opening in it the utopia in which the 'I' recollects itself in dwelling at home with itself" (ibid., p. 156; italics added). Although Levinas does not refer to Heidegger or Bollnow, he seems to criticize both philosophers here. According to Levinas, the home does not open up a sacred (holy) place, but a "u-topia" which has the meaning here of a "non-place" or "non existing place." In such a utopia, the human being is preeminently at home.

\section{Home and world in case of dementia}

The above presentation of the views of Heidegger, Bollnow, Bachelard and Levinas shows that concepts such as house, home and dwelling are used in very different ways. Despite the differences, however, their views converge in one point, that is, that they concern a most fundamental aspect of human existence: being human is to dwell. The writings presented here are not always easy to understand and it needs a great deal of "creative imagination"- - to speak with Bachelard-in order to grasp what they are trying to convey. Nevertheless, I would like to make a few 
comments about the possible relevance of these writings (1) for further home-oriented research in the field of dementia, (2) for the care of patients suffering from dementia and (3) for a philosophical understanding of what it means to suffer from dementia. ${ }^{9}$

(1) A phenomenological approach of home can inspire further research of the ways in which older and vulnerable people experience home. Elderly people tend to lean more heavily on their home environment than younger ones (Krasner 2006). The literature suggests that elderly people generally report a higher level of satisfaction with their current homes than younger ones, although their residential situation might be far from desirable or adequate. Elderly people are generally reluctant to move to a new environment, but they are often forced to do so. For them, home plays a critical role in maintaining a sense of personal identity and independence, sustaining a meaningful existence, and resisting institutionalization (Kontos 1998).

A fine example of home-based research is a qualitative empirical study, based on a Heideggerian interpretive phenomenological methodology, to understand the meaning of living alone from the perspective of older people with Alzheimer's disease or a related dementia (De Witt et al. 2010). One element of this study is especially of interest here. While the focus was on "living alone," that is, on the lifeworld constituents spatiality and intersubjectivity, the empirical findings were for a great deal presented under the heading of a third constituent, that is, temporality, with categories such as "stored time," "dreaded time," and "limited time." This overlap and linkage illustrate the intertwining of the five standard phenomenological constituents of the lifeworld.

Another study of the same authors was also based on Heidegger's, Bachelard's and Bollnow's writings (De Witt et al. 2009). Now the authors focused especially on spatiality and spatial experience. The empirical findings were put in a framework consisting of Heidegger's description of a threshold. The authors described the spatial experience of "living on the threshold" under the heading of four subthemes: (a) being here, (b) being there, (c) being out, and (d) keeping out. Being here refers to being at home in one's own environment: "my home is my centre of my life;" "I feel at home here because I've been here so long" (ibid., p. 276). Being there refers to living in a nursing home, the destination that lay beyond the present homes of the interviewees: "They tried to say ... I needed the old people's home ... They had a bed and I didn't take it. 'Cause I said

\footnotetext{
${ }^{9}$ Of the four authors presented here, only Heidegger refers to a specific disease, namely depression. He argues that in states of depression there is a loss of rapport with things and a change in the "staying with things" (Heidegger 1971, p. 157). This change in relationship with the things in the outside world occurs in many more diseases, especially in psychiatric disorders.
}

what do I need to go up there for? ... They're not gonna shove me around unless I want to go" (ibid., p. 281). Being out was synonymous with going shopping and visiting family members and friends, everyday activities that many of people without dementia take for granted: "I had tickets to go see [name of play], but when it came to it I thought, what's the point of going? ... I'm not gonna remember it anyways" (ibid., p. 282). Keeping out refers to the experience of people with dementia living alone, how the world that came to their doors posed a threat that must be kept out in order to avoid harm: "Well, I don't want to spend money, I don't give it away or anything, but if anybody comes to the door, I don't know them, I just say goodbye" (ibid., p. 283).

In my view, the authors (De Witt et al. 2009) rightly conclude that a Heideggerian interpretation adds depth and breadth to our understanding of the spatial experience of older people with dementia. The spatial experience of these people encompasses places beyond the boundaries of their homes, such as stores, nursing homes, their adult children's homes, and the spatial experience created while getting out to adult day programmes. The threshold phenomenon, as has been described by Heidegger and Bollnow, provides a natural fit with the empirical findings. The interviewed persons differentiated between the being here of living alone in their own homes on the one hand, and the being there of the nursing home and the being out in the community on the other.

(2) Many people suffering from dementia do not live in their own house, but in a home for the elderly, a nursing home, or a psychiatric institution. Care given to these people should focus on making them feel at home in a homelike "surrogate home." Bachelard's very concrete phenomenology can play a role here. The architecture of such a surrogate home can contribute considerably to the well-being of its inhabitants. It is argued that architects of nursing homes for persons with Alzheimer's disease should take into account the needs of patients and their caregivers more carefully (Bermann 2003). Therefore, not only the house, but also the home needs attention. Initiatives have been taken to develop new environmental models of longterm care and safe dwelling places for older people with dementia based on a person-centred view of dementia and an increasing understanding of the lived experience of dementia (O'Sullivan 2000; Davis et al. 2009; Van Hoof and Kort 2009).

Care for persons with dementia increasingly takes place along with the demanding ideal of the so-called emotionoriented care based on the idea of a "person-centred approach" (Kitwood 1997; Sabat 2001). Practising emotion-oriented care means that caregivers should accept the separation of their own lifeworld from that of the person with dementia. However, while emotion-oriented care 
requires caregivers to be emotionally involved, the loss of a shared lifeworld progresses. It is in this context, that some central tenets of the ethics of care are relevant. Tronto suggests that caring be viewed as "a species activity that includes everything that we do to maintain, continue, and repair our 'world' so that we can live in it as well as possible" (Tronto 1993, p. 103). This description of care might be considered to be a late echo of Heidegger's formulation of the fourfold. ${ }^{10}$ According to Heidegger, the basic character of dwelling is to spare and to preserve. Mortal human beings are in the world by preserving the fourfold, that is, by saving the earth, receiving the sky, awaiting the divinities and initiating their own nature. The central question of the ethics of care could therefore be formulated as follows: what do people need from other people in order to experience their world as worth living in and meaningful, in particular, as a home? The answer to this question is not easily given when it comes to people with dementia, especially severe dementia. The capacity of these people to express what is of value in their life is limited, although this capacity must certainly not be underestimated.

(3) Concerning the fundamental level-being human is dwelling - the relevance of a phenomenological approach might even be more considerable. When it comes to vulnerable people such as patients suffering from dementia, phenomenological descriptions drawn from those above may help us to get insight into what it means to dwell while suffering from dementia. In my view, it makes sense to explore if and in what way we can say that a person suffering from dementia has lost his or her capacity to dwell and to be in contact with the things on earth. What does it mean when we say that people suffering from dementia have lost a common shared world of meaning or that they have lost (parts of) the world? Does it make sense to say that they are not at home any more in the world and therefore homeless and "world-less" in a very fundamental sense? Or are they not entirely homeless and "world-less", but just in a gradual way? Has their home or world become smaller? Further philosophical exploration must provide the answers to questions like these.

\section{Conclusion}

In this paper I have presented some phenomenological descriptions of house and home of Heidegger, Bollnow, Bachelard and Levinas. I have conceived home as primarily belonging to spatiality, that is, to one of the five

\footnotetext{
10 Tronto explicitly refers to Heidegger's description of care ("Sorge") as a fundamental aspect of "Dasein" (Tronto 1993, p. 3, $118,125)$.
}

standard constituents of the lifeworld. I have chosen dementia and the care for persons suffering from dementia as an example in order to elucidate the scientific, practical and philosophical significance of a phenomenological approach of home. This paper might be considered as an attempt to switch from a "lifeworld-led health care" (Todres et al. 2007; Dahlberg et al. 2009) to a "home-led healthcare." The idea of home-led health care might lead to an integrative framework that encompasses all five constituents of the lifeworld and function as a philosophical basis of all kinds of existing practices in health care in general and palliative care for persons with dementia in particular.

Open Access This article is distributed under the terms of the Creative Commons Attribution Noncommercial License which permits any noncommercial use, distribution, and reproduction in any medium, provided the original author(s) and source are credited.

\section{References}

Bachelard, G. 1964. The poetics of space. Boston: Beacon Press. Bermann, K. 2003. Love and space in the nursing home. Theoretical Medicine 24: 511-523.

Bollnow, O. 1955. Neue Geborgenheit. Stuttgart: Kohlhammer.

Bollnow, O. 1961. Lived-space. Philosophy Today 5: 31-39.

Dahlberg, K., L. Todres, and K. Galvin. 2009. Lifeworld-led healthcare is more than patient-led care: an existential view of well-being. Medicine, Health Care and Philosophy 12: 265-271.

Davis, S., S. Byers, R. Nay, and S. Koch. 2009. Guiding design of dementia friendly environments in residential care settings. Dementia 8(2): 185-203.

Dekkers, W. 2009. On the notion of home and the goals of palliative care. Theoretical Medicine \& Bioethics 30(5): 335-349.

Dekkers, W. 2010. Persons with severe dementia and the notion of bodily autonomy. In Supportive Care for the Person with Dementia, ed. J.C. Hughes, M. Lloyd-Williams, and G.A. Sachs, 253-261. Oxford: Oxford University Press.

de Visscher, J. 1991. Wonen: de nabijheid van de ander in de bezieling van de dingen. In Wonen: architectuur in het denken van Heidegger, ed. J. de Visscher, and R. de Saeger, 117-146. Nijmegen: SUN.

de Visscher, J. (ed.). 1998. Over de drempel. Van architectonisch minimum tot symbolisch maximum. Best: Damon/Kritak.

de Visscher, J. 1999. Naakt geboren. Over herbergzaamheid, lijfelijkheid, subjectiviteit en wereldijkheid. Leende: Damon.

de Witt, L., J. Ploeg, and M. Black. 2009. Living on the threshold. The spatial experience of living alone with dementia. Dementia 8(2): 263-291.

de Witt, L., J. Ploeg, and M. Black. 2010. Living alone with dementia: an interpretive phenomenological study. Journal of Advanced Nursing 66(8): 1698-1707.

Heidegger, M. 1927. Sein und Zeit. Tübingen: Niemeyer.

Heidegger, M. 1971. Building dwelling thinking. In Poetry, language, thought, ed. Heidegger, M, 145-161. (Translation and introduction: Albert Hofstadter). New York: Harper \& Row.

Hertogh, C.M.P.M., and B.A.M. The. 2008. The loss of a common shared world. Ethical problems in palliative care for people with advanced dementia [Ethische vragen in de palliatieve zorg voor mensen met dementia]. Tijdschrift voor Gerontologie en Geriatrie 39(6): 265-272. 
Hughes, J.C. 2001. Views of the person with dementia. Journal of Medical Ethics 27: 86-91.

Hughes, J.C., S.J. Louw, and S.R. Sabat (eds.). 2006. Dementia. Mind, meaning, and the person. Oxford: Oxford University Press.

Jacobson, K. 2009. A developed nature: a phenomenological account of the experience of home. Continental Philosophical Review 42: $355-373$

Kalis, A., M.H.N. Schermer, and J.J.M. van Delden. 2005. Ideals regarding a good life for nursing home residents with dementia: views of professional caregivers. Nursing Ethics 12(1): 30-42.

Kitwood, T. 1997. Dementia Reconsidered. The Person Comes First. Buckingham, Philadelphia: Open University Press.

Kontos, P.C. 1998. Resisting institutionalization: Constructing old age and negotiating home. Journal of Aging Studies 12: $167-184$

Kontos, P.C. 2005. Embodied selfhood in Alzheimer's disease. Dementia 4(4): 553-570.

Krasner, J. 2006. Accumulated lives: Metaphor, materiality, and the homes of the elderly. Literature and Medicine 24: 209-230.

Lakoff, G., and M. Johnson. 1980. Metaphors we live by. Chicago and London: The University of Chicago Press.

Leder, D. 1990. The absent body. Chicago: University of Chicago Press.

Levinas, E. 1971. Totality and infinity. An essay on exteriority. The Hague/Boston/London: Martinus Nijhoff Publishers.

Meijer, M. 1992. 'Thuis' is het sleutelwoord. De Bazuin 18: 24-26.

Meijer, M. 1993. Alleen God weet nog waar ik woon. Pastorale zorg in het verpleeghuis. Speling: 62-66.

Moore, J. 2000. Placing home in context. Journal of Environmental Psychology 20: 207-217.

O'Sullivan, M. 2000. At home with dementia (http://www. dadhc.nsw.gov.au/NR/rdonlyres/D87FA83D-4E00-446B-A6B97CCE54143820/4024/AtHomeDementia_manual.pdf).
Perkins, H., D. Thorns, A. Winstanley, and B. Newton. 2002. The study of 'home' from a social scientific perspective: An annotated bibliography, 2nd ed. New Zealand: Canterbury.

Phinney, A., and C.A. Chesla. 2003. The lived body in dementia. Journal of Aging Studies 17: 283-299.

Sabat, S.R. 2001. The Experience of Alzheimer's Disease. Life Through a Tangled Veil. Oxford, UK: Blackwell Publishers.

Spiegelberg, H. 1982. The phenomenological movement. A historical introduction, Third and enlarged edition ed. The Hague/Boston/ London: Martinus Nijhoff Publishers.

Svenaeus, F. 2000. Das unheimliche-towards a phenomenology of illness. Medicine, Health Care and Philosophy 3: 3-16.

Svenaeus, F. 2001. The Hermeneutics of medicine and the phenomenology of health. Dordrecht: Kluwer Academic Publishers.

Svenaeus, F. 2002. The phenomenology of health and illness. In Handbook of Phenomenology and Medicine, ed. S.K. Toombs, 87-108. Dordrecht: Kluwer Academic Publishers.

Todres, L., K. Galvin, and K. Dahlberg. 2007. Lifeworld-led healthcare: revisiting a humanising philosophy that integrates emerging trends. Medicine, Health Care and Philosophy 10: $53-63$.

Toombs, S.K. (ed.). 2001. Handbook of Phenomenology and Medicine. Dordrecht: Kluwer Academic Publishers.

Tronto, J.C. 1993. Moral Boundaries. A Political Argument for an Ethic of Care. New York/London: Routledge.

van Hoof, J., and H.S.M. Kort. 2009. Supportive living environments. A first concept of a dwelling designed for older adults with dementia. Dementia 8(2): 293-316. 